\title{
Diet and Prey Availability of Terrestrial Insectivorous Birds Prone to Extinction in Amazonian Forest Fragments
}

\author{
Luiz Augusto Macedo Mestre ${ }^{1,2,3^{*}}$, Mario Cohn-Haft ${ }^{4}$ and Manoel Martins Dias ${ }^{2}$ \\ ${ }^{1}$ South Dakota State University; Geographic Information Science Center of Excellence; 1021; Medary Ave.; Wecota \\ Hall, 57007; Brookings - SD - USA. ${ }^{2}$ Universidade Federal de São Carlos; Departamento de Ecologia e Biologia \\ Evolutiva; C.P.: 676; 13.565-905; São Carlos - SP - Brasil. ${ }^{3}$ Universidade Federal do Paraná; Rua Pioneiro, 2153; \\ 85950-000; Palotina - PR - Brasil. ${ }^{4}$ Instituto Nacional de Pesquisas da Amazônia; C.P.: 478; 69083-000; Manaus - \\ AM - Brasil
}

\begin{abstract}
This study compared niche breath, prey size, and diet variability in two pairs of sympatric species of terrestrial insectivorous birds, each pair containing one species that can persist in small forest fragments and one that does not. The pairs were Myrmeciza ferruginea and Sclerurus rufigularis; and Formicarius colma and F. analis, respectively. The prey availability in forest fragments was also sampled and compared to the availability in continuous forests. Niche breath indices did not differ between pair members, but diet variability differed in the opposite direction from that hypothesized. Although the two bird species most vulnerable to fragmentation fed on larger prey than less vulnerable species, prey availability, including that based on prey size did not differ among fragmented versus continuous forest sites. Thus, diet per se appeared not to be an important cause of extinctionproneness in these species. The simplest explanation proposed, that vulnerability to fragmentation was directly related to territory size, requires testing. However, it was consistent with observations that the bird species feeding on larger prey also need larger territories.
\end{abstract}

Key words: Amazonian forests, Bird diet, Forest fragmentation, Insectivores, Formicarius colma, Formicarius analis, Myrmeciza ferruginea, Sclerurus rufigularis

\section{INTRODUCTION}

Forest fragmentation affects the composition of forest bird communities, especially in the humid tropics where the rates of forest destruction are high and where birds are generally more specialized in their foraging tactics, live in more specific habitats, and need larger territories than in temperate forests (Stouffer and Bierregaard, 1995; Hagan et al., 1996). Different bird species react differently to deforestation (Canaday, 1996). Species with greater extinction-proneness generally are at their geographic or elevational limits. Higher vulnerability may also be related to life history and ecological characteristics, such as body size, small populations, habitat specialization, or low survival rate (Kattan et al., 1994). Bird species negatively affected by the forest fragmentation are generally restricted to the interior of primary forests and have little ability to use second growth and forest edges (Offerman et al., 1995).

In central Amazonia, bird capture rates of some canopy and gap specialists have increased after

*Author for correspondence: luiz.mestre@ gmail.com 
forest fragmentation. However, most common understory insectivorous species disappeared from the isolated forest fragments during first years of isolation (Stouffer and Bierregaard, 1995). After this decline, ant followers and some obligate flock species returned to the fragments surrounded by second growth. Despite the fact that some species of terrestrial insectivores were still observed in the forest remnants and second growth sites, this group seems to be one of the most affected by forest fragmentation (Stouffer and Bierregaard, 1995; Stratford, 1997; Stratford and Stouffer, 1999; Borges and Stouffer, 1999; Ferraz et al., 2003; Ferraz et al., 2007).

Several hypotheses have been proposed to explain the decline of understory insectivorous birds in forest fragments, including physiological sensitivity to microclimatic changes, habitat specificity, dispersal ability, and food scarcity (Sekercioglu et al., 2002). The food scarcity hypothesis is frequently proposed, because forest fragmentation generally alters the arthropod communities in the region (Brown, 1991; Offerman et al., 1995; Didham et al., 1996; Didham, 1997; Stratford, 1997). Thus, the decline of some groups of litter invertebrates and modifications in biomass of understory arthropods (Didham et al., 1996; Malcolm, 1997) could directly affect the resources and consequently the maintenance of bird populations (Burke and Nol, 1998). Moreover, possible trophic specialization of terrestrial insectivores may allow some bird species to remain in forest fragments, because different habitat preferences and foraging tactics can determine the consumption of different types and number of prey (Sherry, 1984; Cohn-Haft, 1995).

If sensitivity to fragmentation is associated with diet, it is reasonable to expect that species with relatively flexible diets will be most likely to persist in forest remnants. We tested this hypothesis by examining if the fragmentationresistant species have more flexible diets than the vulnerable species. We compared niche breath, prey size and diet variability among four species of terrestrial insectivorous birds (Myrmeciza ferruginea, Sclerurus rufigularis, Formicarius colma, and Formicarius analis) and quantified prey availability in forest fragments. We attempted to control variables other than vulnerability to fragmentation by comparing pairs of species, in which one member can persist in forest fragments and one does not. Our hypothesis was that species more vulnerable to forest fragmentation will differ in diet composition from those resistant to fragmentation, linking the diet characteristics with vulnerability to fragmentation.

\section{METHODS}

\section{Study sites}

Fieldwork was conducted in terra firme (upland, non-flooded) tropical rain forest in the reserves managed by the Biological Dynamics of Forest Fragments Project (BDFFP, a collaborative research project of the Instituto Nacional de Pesquisas da Amazônia and the Smithsonian Institution), located approximately $80 \mathrm{~km}$ north of Manaus, Amazonas, Brazil (2²0'00"s / $60^{\circ} 00^{\prime} 00^{\prime} \mathrm{W}$ ) (Fig. 1). Surrounding the ranches and embedded forest fragments (see below), continuous primary forest extends to the east, west and north, occasionally interrupted by roads, but forest to the south has been progressively disturbed. The continuous forest has a relatively closed canopy, approximately $30 \mathrm{~m}$ high, and a relatively open understory dominated by palms.

Prey availability data were also collected from seven forest fragments that were created by the clearing of land for cattle ranches. These fragments are separated by distances of 70 to 650 $\mathrm{m}$ from the nearest continuous forest (see Lovejoy et al. [1986] for descriptions of the individual fragments).

Seasonality at the sites is relative to other lowland moist forests (Gentry 1990). Annual rainfall averages about $2200 \mathrm{~mm}$, with a peak in March and April (>300 mm/month) and a dry season from July to September ( $<100 \mathrm{~mm} /$ month). The mean annual temperature is $26.7^{\circ} \mathrm{C}$ (Salati et al., 1991). More detailed descriptions of these sites are given by Lovejoy et al. (1983), Gentry (1990), and Stouffer and Bierregaard (1995). The complete avifauna of the sites is presented by Cohn-Haft et al. (1997).

\section{Bird species}

The present study analyzed the diets of two pairs of bird species in the same trophic guild, with similar weight and bill length (size data from Bierregaard, 1988): Formicarius colma (Rufouscapped Antthrush, Formicariidae, 46 g.) and Formicarius analis (Black-faced Antthrush, Formicariidae, 62 g.); Myrmeciza ferruginea (Ferruginous-backed Antbird, Thamnophilidae, 
25 g.) and Sclerurus rufigularis (Short-billed Leaftosser, Furnariidae, $21 \mathrm{~g}$.). The first species of each pair is present in the forest fragments as well as in continuous forests, whereas the second occurs only in pristine, unfragmented forests (Stouffer and Bierregaard, 1995; Stratford and
Stouffer 1999). This paired design attempted to control the factors other than diet that could influence the susceptibility to fragmentation (Felsenstein, 1985; Harvey and Pagel, 1991).

These four species of terrestrial insectivorous birds forage mainly in the leaf litter.

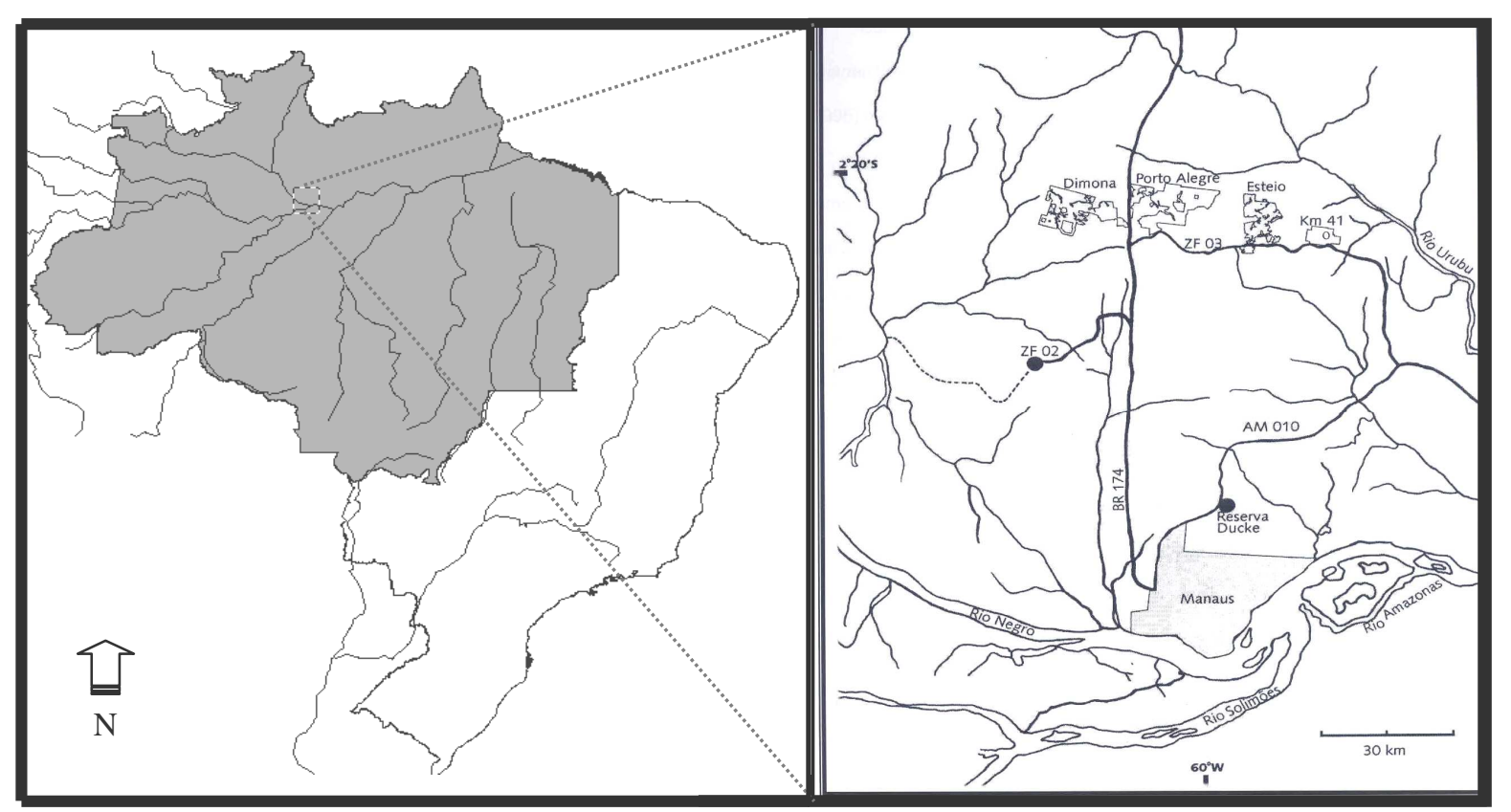

Figure 1 - Study sites. Brazil and legal Brazilian Amazon (dark); detail of study sites on the right (adapted from BDFFP databases).

Furthermore, various other aspects of their biology and ecology have been studied in the same areas, such as comparisons of body dimensions (Bierregaard, 1988), territory sizes (Stouffer, 1997; Stratford, 1997), interspecific interactions (Stouffer, 1997), and population persistence in the studied fragments (Stouffer and Bierregaard, 1995; Stratford, 1997; Stratford and Stouffer, 1999).

\section{Diet sampling}

The study was conducted between February and October 2001, and April and May 2002. The birds were localized by playback with audio equipment. When an individual replied, we set one or two mist-nets and attracted the birds with continued playback. Each capture site was noted to distribute sampling spatially and avoid recapture. The birds were captured between 0700 and $1500 \mathrm{~h}$, so that the captured birds could forage before and after the treatment. Each bird was identified, marked by cutting the tip of a secondary remige, and induced to regurgitate by oral administration of tartar emetic $(1.5 \%$ solution of antimony and potassium tartar, $0.8 \mathrm{ml} / 100 \mathrm{~g}$ ). The birds were placed in a cardboard box for $30 \mathrm{~min}$ and then released. This method allowed diet analysis with low mortality rates (Robinson and Holmes, 1982; Poulin et al. 1994abc, Mallet-Rodrigues et al. 1997), but see Jonson et al. (2001). All the birds induced to regurgitate survived to release, and two of them were recaptured. Those recaptured individuals were not induced to regurgitate.

Diet data were collected only in primary continuous forest (Porto Alegre, Dimona, and Esteio farms, including the reserves Florestal, Gavião, and $K m 41$ ). No individuals were sampled in the fragments due to the absence of the two extinction-prone species in these sites and low abundance of the other two species in those areas; this avoided inadequate sample sizes and the threat 
of mortality of these few individuals in fragments, where the presence of an undisturbed avifauna is essential to other studies conducted there.

\section{Diet analyses}

Bird stomach contents were preserved in $80 \%$ alcohol and processed using a stereo-microscope. Diagnostic prey fragments were identified and sorted into categories as more precise taxonomic level as possible, mainly in order level and life stage (larva or adult). The prey fragments were subsequently matched to determine the minimum number of individuals per prey category. For example, three orthopteran mandibles represented three orthopterans if they all differed in size or shape or if all came from the same side of the arthropod body; they represented two individuals if two of the three could be matched as a pair (Cohn-Haft, 1995). References used to aid in the identification of prey fragments included Borror et al. (1981), CSIRO (1979), and Chapman and Rosenberg (1991). We reexamined earlier samples after becoming familiar with the range of prey fragments. All prey fragments known to represent prey items were successfully identified, and there was no "unidentified" prey category.

The prey size was estimated for $96 \%$ of all diet components. These estimates were calculated using linear regression from more than 150 arthropods collected in the prey availability samples. Regressions were made using diagnostic prey fragments (such as spider fangs or orthopteran mandibles) and total prey size (with same taxonomic level of diet samples). We estimated the prey size only when this regression had a highly significant slope, different from zero $(\mathrm{p}<0.001)$, and Pearson correlation coefficient superior to 0.90 (Rosenberg, 1993).

\section{Diet indices}

Indices were calculated for each species, assuming that the diet composition was a trait that could be characterized for an entire species (or population), that regurgitated samples from different individuals at different times represented a random sample of the dietary variation found within the population, and that diet variation among individuals was equivalent to that within individuals over the study period. Limiting sampling to a single region controlled possible geographic variation in the diet of the same species.
Niche breadth was calculated using the inverse of Simpson's (1949) Index: $\mathrm{S}=1 / \Sigma \mathrm{p} i^{2}$, where $\mathrm{p} i$ is that proportion of the diet comprised by the $i$ th prey category $(\Sigma=$ sum). This index is mathematically related to richness and to the Shannon Diversity Index, but differs only in the importance given to most-represented categories, weighting abundance most heavily (Hill, 1973; May, 1975). Species with a flexible diet should have larger niche breath and we expected that the resistant species fed on a more diverse prey "community".

The variability in stomach contents among individuals within a species was calculated with a population dietary heterogeneity index (PDH; Sherry, 1984; 1990). PDH compares the diet samples of each species as $G_{\mathrm{H}} / \mathrm{df}$, where $G_{\mathrm{H}}$ is the $G$ statistic for heterogeneity (Sokal and Rohlf, 1981), and df is the degrees of freedom: (no. samples - 1) $\mathrm{x}$ (total no. prey categories in all samples for the species -1 ). This index measures the "prey category by stomach sample" interaction (Sokal and Rohlf, 1981). In this study, an arbitrary small constant (0.0001) was added to every cell, because $G_{\mathrm{H}}$ could not be calculated on tables with zero cells (prey categories not represented in a given sample) (Cohn-Haft, 1995). We expected that extinction-resistant species have more heterogeneous diets.

\section{Prey availability sampling}

The leaf litter arthropod communities were sampled simultaneously with diet sampling from February to September 2001. We collected the samples in four 1ha fragments, three 10ha fragments, and at three sites within the continuous forests, in the same areas where the birds were captured. The sampling sites were divided in 25 equal-sized squares, and we randomly selected five of these sites. We collected an area of 30x30 $\mathrm{cm}$ of leaf liter in the center of each selected site. The leaf litter was promptly placed in a plastic bag for sorting at the field camp. Sampled litter was examined in a plastic tray, and leaves were sifted ( $2 \mathrm{~mm}$ mesh). Invertebrates (except the mites and collembolans) $>0.5 \mathrm{~mm}$ in length were collected with tweezers and preserved in $80 \%$ alcohol. They were identified later in the lab, being organized in three size classes $(0.5-2 \mathrm{~mm}, 2-6 \mathrm{~mm}$, and $>6 \mathrm{~mm})$ and sorted into broad taxonomic groups, order and life stage (larvae or adult). 
The means of proportions of total arthropods, and proportion of each taxon among the continuous forests, 1-ha, and 10-ha fragments, were compared with Kruskal-Wallis test complemented by Dunn's test. The abundance and richness values of arthropods were also compared between the wet and dry seasons with Mann-Whitney test. Abundance and proportions of invertebrates in the three size classes were compared between the fragments and continuous forests with MannWhitney U tests.

\section{Comparative analyses}

We tested the hypothesis that dietary indices of the vulnerable species in each pair differed from those of the corresponding fragmentation-resistant species, and predicted that the direction of the difference was the same in both pairs. To compare these indices within the pairs, we estimated by bootstrapping the means and degrees of freedom of the index for each species (Efron, 1982, Lanyon, 1987). The bootstrapping method estimated these values for each species, resampling 100 (in this case) pseudoreplicates of each index from the original sample, assuming that these samples were random and represented the diet of the whole population (Cohn-Haft, 1995). Thus, the three dietary indices were calculated 100 times obtaining means and standard deviations and permitting comparisons with Student $t$-tests. We used Mann-Whitney U test when the assumptions to run parametric tests were not met.

To test the prediction that vulnerable species eat prey of different sizes from those eaten by resistant species, the values of prey sizes were compared within the pairs using Mann-Whitney U tests.

\section{Sample adequacy assessment}

The sample adequacy for each species was assessed by generating prey type saturation curves (by taxonomic order and life stage), in addition to the bootstrap replicates, which provided the confidence estimates for each pairwise comparison. If a species' diet was adequately characterized in richness, addition of samples should add no new prey types to the known diet, approaching an asymptote with increasing sample size. To avoid the problem of order of inclusion, the saturation curves for each species were drawn using the means and standard deviations obtained by a random subsampling procedure (Cohn-Haft, 1995).

\section{RESULTS}

The present analyses are based on examination and identification of over 1200 prey items from 39 regurgitated samples: 16 from Myrmeciza ferruginea, six from Sclerurus rufigularis, eight from Formicarius colma, and nine from $F$. analis. Twenty-one prey categories were identified, including 12 insect orders, beetle and dipteran larvae, three arachnid orders, egg cases (of spiders and insects), gastropod mollusks (snails), worms, and small vertebrates (lizards or frogs). Individual samples contained from four to 192 prey items.

\section{Diet composition}

Myrmeciza ferruginea fed mainly on orthopterans, egg cases, spiders, harvestmen (Opiliones), and beetles ( $>80 \%$ of diet). The main preys of Sclerurus rufigularis were spiders, egg cases, ants, beetle larvae, and adult beetles. The diets of Formicarius colma and $F$. analis were comprised mainly of ants, orthopterans, dipteran larvae, and adult beetles (Fig. 2).

Contrary to our expectations, pair members were more similar to one another in their overall diets than were extinction-prone or resistant species (Fig. 2). The two Formicarius species did not differ in the proportions of prey types common to both ( $\mathrm{p}>0.05)$. M. ferruginea and S. rufigularis differed in the proportions of harvestmen (Opiliones), orthopterans and beetle larvae (MannWhitney, p<0.05). They fed on similar proportions of egg cases, beetles, spiders and ants ( $>>0.10)$.

Prey saturation curves indicated that only $M$. ferruginea approached an asymptote. This suggested that population dietary richness of the other species would likely continue to increase with additional sampling (Fig. 2).

The numbers of prey types consumed by the four species were similar $(M$. ferruginea $=15, S$. rufigularis $=13, F$. colma $=15, F$. analis $=16$ ). Results of bootstrap replication indicated that the differences in population dietary richness within the four species were also not statistically different ( $t$-tests, $\mathrm{p}>0.05$ ) (Table 1). The diet diversity was higher in the smaller pair, with $S$. rufigularis presenting the most diverse diet (6.24) and $F$. analis the least (2.77). The comparisons of bootstrapping results showed that population dietary diversity was similar within species pairs ( $t$-tests, $\mathrm{p}>0.05$ ), but widely different between the 
two pairs $(\mathrm{p}<0.01)$, and the smaller pair $(M$. ferruginea and $S$. rufigularis) having more diverse diets (Table 1). The diet variability (PDH) among individuals showed different trends in the two pairs. The resistant species $F$. colma had a more variable diet than $F$. analis; however, in the other comparison, the resistant species $M$. ferruginea had the lower PDH. Bootstrapping results indicated that both these differences were statistically significant $(t$-test, $\mathrm{p}<0.01$ and $\mathrm{p}<0.05$, respectively; Table 1).

In pairwise comparisons the differences between pair members did not consistently follow the predicted directions; the two pairs differed in direction for every index. Furthermore, with one exception, there were no statistically significant differences in diet indices between pair members, based on bootstrap-generated means. Members of each pair differed significantly in PDH, but again the direction of these differences was not consistent in both pairs.

In general, prey consumption did not vary by season. The abundance of prey consumed, proportions of prey items, and niche breath showed no seasonal differences $(p>0.05)$. The size of prey consumed differed seasonally in two of the four species; S. rufigularis $(\mathrm{p}=0.009)$ and $F$. colma $(\mathrm{p}=0.05)$ ate larger prey items in the dry season.



Figure 2 - Proportion of prey items consumed by the four terrestrial insectivorous species, number of samples in parentheses. Egg cases include spider and insect cases. (L) = Larvae. "Other" category includes the sum of all prey types that individually comprised $<2 \%$ of each species' diet; F. analis = Blattodea, Diplopoda, Coleoptera larvae, Homoptera, Annelida, Mollusca, Neuroptera, Opiliones, Uropigy and Vertebrates; F. colma = Blattodea, Hemiptera, Homoptera, Isoptera, Coleoptera larvae, Neuroptera, Egg Cases, Opiliones and Vertebrates; M. ferruginea = Blattodea, Diptera larvae, Homoptera and Opiliones; S. rufigularis = Dermaptera, Diptera larvae, Coleoptera larvae, Homoptera, Lepidoptera, Annelida and Vertebrates. 


\section{Prey sizes}

The fragmentation-vulnerable species fed on larger prey items than the resistant species (MannWhitney test: $\mathrm{U}_{\mathrm{M} \text {.ferruginea } \times \text { S.rufigularis }}=5591.5, \mathrm{p}=$ $0.0001 ; \mathrm{U}_{\text {F.colma } \times \text { F.analis }}=60833, \mathrm{p}=0.016$ ), even though bill sizes were similar. The average of all prey items for each estimated size was significantly higher in $S$. rufigularis and $F$. analis than in their respective pair members (Mann-
Whitney, $\mathrm{U}_{\text {M.ferruginea }} \times$ S.rufigularis $=60.5 \mathrm{p}<0.001$; $\left.\mathrm{U}_{\text {F.colma } \times \text { F.analis }}=55971 \mathrm{p}<0.03\right)$. Even when the prey types were compared separately, Formicarius colma fed on smaller orthopterans, ants, and dipteran larvae than $F$. analis $(\mathrm{p}<0.001)$. The differences were also significant in the other pair, where $M$. ferruginea ate smaller egg cases and spiders than $S$. rufigularis (Table1).

Table 1 - Dietary indices for each species. Fragmentation-resistant species shown at right. Mean and standard deviation of indices were obtained by bootstrapping. Pairwise comparisons were made with $t$-tests (indices) and Mann-Whitney U test (prey size and prey items); NS = not statistically significant; $*=\mathrm{p}<0.05 ; * *=\mathrm{p}<0.01 ; * * *=$ $\mathrm{p}<0.001$; direction of comparison is if the diet index value for vulnerable species is greater or lesser than that for resistant species.

\begin{tabular}{|c|c|c|c|c|c|}
\hline & \multicolumn{2}{|c|}{ Vulnerable } & \multicolumn{2}{|c|}{ Resistant } & Comparison (direction) \\
\hline & \multicolumn{2}{|c|}{ F. analis } & \multicolumn{2}{|c|}{ F. colma } & \\
\hline & Value & Mean \pm SD & Value & Mean $\pm \mathrm{SD}$ & \\
\hline Richness & 16 & $13.60 \pm 1.3$ & 15 & $12.91 \pm 1.61$ & NS (>) \\
\hline Niche breadth & 2.77 & $2.74 \pm 0.34$ & 3.28 & $3.26 \pm 0.39$ & NS $(<)$ \\
\hline PDH & 1.26 & $1.10 \pm 0.17$ & 4.44 & $3.51 \pm 1.60$ & $* *(<)$ \\
\hline Prey items & 502 & $62.7 \pm 56.3$ & 304 & $33.7 \pm 12.8$ & $\mathrm{NS}(>)$ \\
\hline \multirow[t]{3}{*}{ Prey Size } & & (median) $7.9 \mathrm{~mm}$ & & (median) $7.7 \mathrm{~mm}$ & $*(>)$ \\
\hline & \multicolumn{2}{|c|}{ S. rufigularis } & \multicolumn{2}{|c|}{ M. ferruginea } & \\
\hline & Value & Mean \pm SD & Value & Mean $\pm \mathrm{SD}$ & \\
\hline Richness & 13 & $11.33 \pm 1.42$ & 15 & $13.58 \pm 0.94$ & NS $(<)$ \\
\hline Niche breadth & 6.24 & $5.75 \pm 1.49$ & 6.17 & $6.04 \pm 0.39$ & $\mathrm{NS}(>)$ \\
\hline PDH & 1.92 & $1.35 \pm 0.40$ & 1.01 & $0.92 \pm 0.1$ & $* \quad(>)$ \\
\hline Prey items & 123 & $20.5 \pm 12.01$ & 255 & $15.9 \pm 6.7$ & NS $(<)$ \\
\hline Prey Size & & (median) $8.2 \mathrm{~mm}$ & & (median) $6.3 \mathrm{~mm}$ & $* * *(>)$ \\
\hline
\end{tabular}

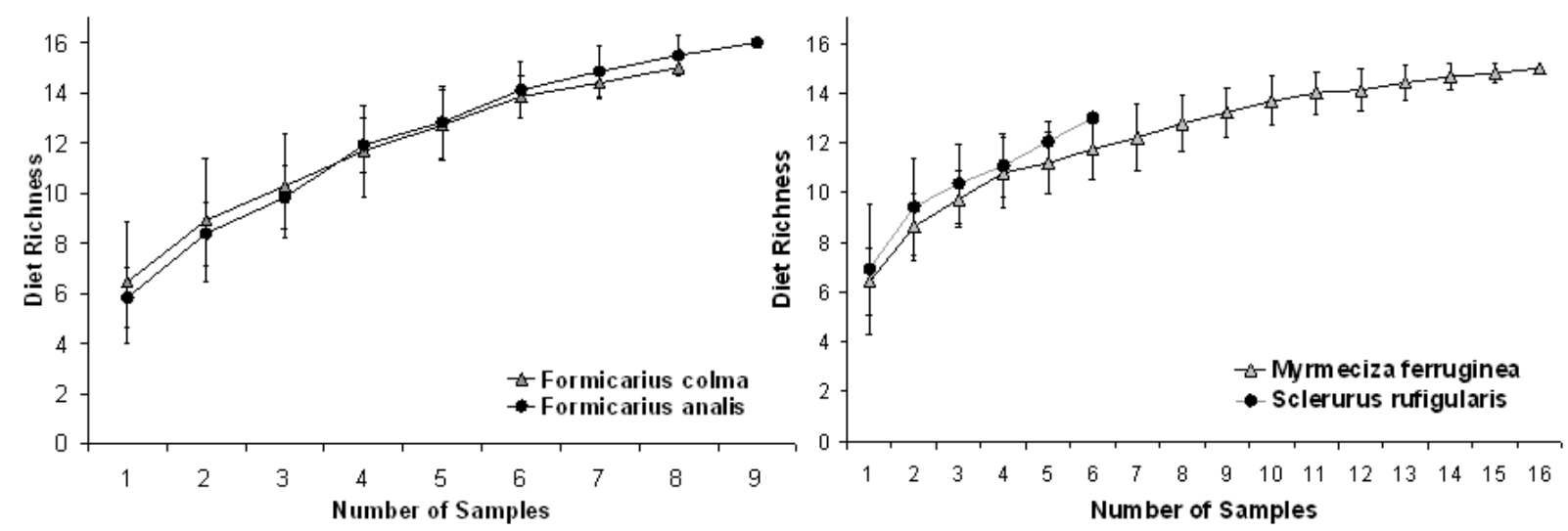

Figure 3 - Prey saturation curves. For each number of samples, symbols represent mean and standard deviation of 100 random collections of that many samples (without repetition) from the total pool of collected samples for that species. This approach eliminates effects of sample order on curve shape (Cohn-Haft, 1995). Gray triangles represent fragmentation-resistant species and black circles vulnerable species. 


\section{Prey availability}

The most abundant invertebrates in the leaf litter were ants $(>60 \%)$, followed by termites, spiders, whipscorpions, beetles and isopods; between 0.5 and $2 \mathrm{~mm}$. The proportions of available prey (all prey items) did not differ between the continuous forests, 1 ha and 10 ha fragments (Kruskal-Wallis, $p>0.05)$. In the comparisons of proportions of each separate prey category, only the proportion of beetles was significantly higher in 1 ha and 10 ha fragments than in continuous forest (KruskalWallis, $\mathrm{p}=0.04$ ). The abundance and proportions of any of the three size classes of invertebrates did not differ between fragments and continuous forest $(p>0.05)$. Total invertebrate abundance and richness were significantly higher in the rainy than dry season ( $t$-test, respectively $\mathrm{p}=0.003, \mathrm{p}=$ 0.02). When proportions of each prey taxon were compared, differences were detected only in beetles and beetle larvae $(t$-test, $\mathrm{p}<0.05)$.

\section{DISCUSSION}

Diet differences between the pair members were not consistently related to vulnerability to fragmentation. Although the two most vulnerable species fed on larger prey than less vulnerable species, prey availability (including by size class) did not differ among fragmented versus continuous forest sites. This result suggests that the vulnerability to fragmentation is not directly influenced by diet in these species. However, extinction proneness could be indirectly linked to prey size or to prey quality. For example, the individuals of a species which requires larger prey might not survive in small fragments, because they must have larger territories to find these preys.

The only diet index that showed statistically significant differences between the fragmentationresistant and vulnerable species, population dietary heterogeneity $(\mathrm{PDH})$, differed in the opposite direction from that predicted in one of the pairs. That pair, M. ferruginea and S. rufigularis, may not offer adequate controls of confounding variables. Although the two species are similar in size and shape, they are from different avian families and may have important differences in foraging behavior. It is possible that these differences influenced diet indices in the ways unrelated to vulnerability to fragmentation. In fact, prey composition differed more strongly in this pair than between the two Formicarius spp.
However, no better comparison could be made from among the avifauna present at study site. In any case, this difficulty draws attention to the importance of unique species traits in determining the responses to habitat degradation.

In pairwise comparisons, the heavier species showed lower variability in prey, and although non-significant, they consumed more prey items, had smaller niche breath, and higher diet richness. These characteristics could therefore be related to size or weight, as much as to the extinction proneness of these species. The correlations with body mass and number of prey items, and the close relationships between PDH and niche breath reinforced this hypothesis (Sherry, 1984).

The leaf litter arthropod abundance observed in this study showed similar taxonomic dominance to that found in other studies conducted at the same sites (Malcolm, 1997; Didham, 1996). Pitfall trap method used by Malcolm (1997) showed that fragments and continuous forest have similar total terrestrial arthropod biomass. Effects of fragmentation on total density of litter insects also were not significant in Didham's (1996) study; but when isolated groups were compared, such as beetles (Klein, 1989; Didham, 1996), termites (Souza, 1989; Souza and Brown, 1994), and ants (Lovejoy et al., 1986; Vasconcelos, 1988; Harper, 1989; Didham, 1996), all declined in abundance with fragmentation. However, the density of these vulnerable groups could not be influencing the terrestrial insectivorous birds, because the proportions of these consumed preys did not differ between the bird species. If the classification of prey to taxonomic order was inadequate to detect important differences among the diets, then it would be conceivable that real diet differences not detected in this study played a role. However, the level of identification used here, and even coarser classifications, were sufficient for detecting ecologically important differences in other studies (e.g., Sherry, 1984; Cohn-Haft, 1995). More likely, other factors not directly related to diet and not examined in this study could be determining the extinction proneness of these species.

Other hypotheses include different physiological demands, specific microhabitats, and territory size. Territory size of $M$. ferruginea ranges from 5 to 10 ha, whereas that of $S$. rufigularis exceeds 20 ha (P.C. Stouffer, unpubl. data). Similarly, F. colma and $F$. analis have territories of roughly 8 and 16 ha, respectively (Stouffer, 1997). This alone could be sufficient to explain the absence of the two 
vulnerable species from 1 ha and 10 ha fragments. The determinants of territory size are unknown and may be related to diet. Specifically, the use of larger prey (as found in the vulnerable species) may require larger territory sizes to encounter adequate numbers of these preys.

The territory size can be an important feature related to fragmentation effects; however a unique mix of factors probably influences the survival of each species. Some of these factors are inability of the birds to use the deforested landscapes (thus preventing dispersal and recolonization; Sekercioglu, 2002), flexibility in adaptation to different microhabitats, and physiological sensitivity to the changes in microclimate associated with fragmentation (e.g. Canaday, 1996; Ford et al., 2001). New studies must address comparisons of territory utilization, foraging, breeding, and movement patterns related to forest disturbances. Moreover, all these important data need to be used as a basis for understanding and conserving bird species in the Brazilian territory.

\section{ACKNOWLEDGMENTS}

We thank to L. Araújo, J. Barlow, S. Borges, R. Cintra, J. Garavelo, A. Henriques, C. McCain, L. Naka, N. Nordi, P. Stouffer, J. Salatiel, E. Venticinque, J. Verani, L. Zanette and C. Zartman for helpful comments on this paper. The project was supported by PPGERN-UFSCar, CAPES, BDFFP-INPA/SI and WWF. This paper is number 549 in the BDFFP technical series and contribution 15 in the Amazonian Ornithology technical series of the INPA Scientific Collections Program.

\section{RESUMO}

Dieta e disponibilidade de presas de aves insetívoras terrestres em fragmentos florestais amazônicos. As aves insetívoras terrestres são um dos grupos mais vulneráveis à fragmentação de florestas tropicais; no entanto algumas espécies desta guilda ainda sobrevivem em fragmentos florestais e em florestas secundárias. Se a sensibilidade destas aves à fragmentação de florestas estivesse associada à dieta, então espécies com a dieta relativamente flexível teriam maior propensão em persistir nos fragmentos florestais.
Este estudo comparou sobreposição trófica, amplitude de nicho, tamanho de presas e variabilidade de dieta de dois pares de espécies de aves insetívoras terrestres, onde cada par foi composto por uma espécie que persiste nos fragmentos e outra que não: Myrmeciza ferruginea e Sclerurus rufigularis; Formicarius colma e Formicarius analis, respectivamente. A disponibilidade de presas foi também amostrada e comparada entre os fragmentos florestais e a floresta contínua. Os índices de amplitude de nicho não foram significativamente diferentes entre membros dos pares, e a variabilidade de dieta diferiu no sentido oposto aquele previsto. Embora as espécies mais vulneráveis tenham consumido presas maiores que as espécies mais resistentes, a disponibilidade de presas não diferiu significativamente entre os fragmentos e a floresta contínua. Assim, pode ser concluído que dieta não é o principal determinante na extinção destas espécies nos pequenos fragmentos florestais. A mais simples explicação proposta, de que vulnerabilidade à fragmentação é diretamente relacionada ao tamanho do território, requer testes. No entanto, a probabilidade de que estas aves precisem de territórios maiores por que predam invertebrados maiores é consistente com observações não publicadas feitas nas áreas de estudo.

\section{REFERENCES}

Bierregaard, R. O. (1988), Morphological data from understory birds in terra firme forest in the central Amazonia basin. Rev Bras Biol., 48, 169-178.

Borges, S. and Stouffer P. (1999), Bird communities in two types of anthropogenic successional vegetation in central Amazonia. The Condor 101, 529-536.

Borror, D. J.; DeLong D. M. and Tripplehorn (1981), An introduction to the study of insects. Saunders. NY.

Brown Jr., K. S. (1991), Conservation of Neotropical Environments: insects as indicators. In- The conservation of insects and their habitats (R.E.S. Symposium XV) Academic Press, London.

Burke, D. M. and Nol, E. (1998), Influence of food abundance, nest-site habitat, and forest fragmentation on breeding ovenbirds. The Auk, 115 (1), 96-104.

Canaday, C. (1996), Loss of insectivorous birds along a gradient of human impact in Amazonia. Biol. Conserv., 77, 73-77.

Chapman, A. and Rosenberg K. V. (1991), Diet of four sympatric Amazonian Woodcreepers (Dendrocolaptidae). The Condor, 93, 904-915. 
Cohn-Haft, M. (1995), Dietary specialization by lowland tropical rainforest birds: forest interior versus canopy and edge habitats. Master Thesis, Tulane University - USA.

Cohn-Haft, M.; Whittaker, A. and Stouffer, P. C. (1997), A new look at the "species-poor" central Amazon: The avifauna north of Manaus, Brazil. In Neotropical Ornithology Honoring Ted Parker ed. J. V. Remsen Jr. Biol Conserv, 48, pp. 205-235.

C.S.I.R.O. (1979), The insects of Australia. Commonwealth Scientific and Industrial Research Organization, Division of Entomology. Melbourne University Press, Carlton, Victoria, pp. 1030.

Didham, K. R. (1996), The effects of Forest fragmentation on leaf-litter invertebrates in central Amazonia. PHD Thesis, University of London, UK.

Didham, K. R. (1997), The influence of edge effects and forest fragmentation on leaf litter invertebrates in central Amazonia. In- Tropical Forest Remnants Ecology, Management, and Conservation of Fragmented Communities, ed. Laurance W. F. and R. O. Bierregaard. University of Chicago Press, Chicago, pp. 55-70.

Efron, B. (1982), The jackknife, the bootstrap and other resampling plans. Society for Industrial and Applied Mathematics CBMS - NSF, Monographs Philadelphia, PA.

Felsenstein, J. W. (1985), Phylogenies and the comparative method. Amer Nat, 125, 1-15.

Ferraz, G.; Nichols, J. D.; Hines, J. E.; Stouffer, P. C.; Bierregaard Jr., R. O. and Lovejoy T. E. (2007),. A Large-Scale Deforestation Experiment: Effects of patch area and isolation on Amazon birds. Science, 315 (5809), 238-241.

Ferraz, G.; Russell, G. J.; Stouffer, P. C.; Bierregaard, R. O.; Pimm, S. L. and Lovejoy T. E. (2003), Rates of species loss from Amazonian forest fragments. Proc Nattl Acad Sci USA, 100 (24), 14069-14073.

Ford, H. A.; Barret, G.; Saunders, D. and Recher H. (2001), Why have birds in the woodlands of Southern Australia declined? Biol Conserv, 97, 71-88.

Gentry, A. H. (1990), Four Neotropical Rainforests. New Haven, Yalle University Press.

Hagan, J. M.; Haegen, W. M. V. and Mckinley, P. (1996), The early development of forest fragmentation effects on birds. Conserv Biol, 10 (1), 188-202.

Harper, L. H. (1989), The persistence of ant-following birds in small Amazonian forest fragments. Acta Amaz, 19, 249-263.

Harvey, P.H. and Pagel M. D. (1991), The comparative method in evolutionary biology. Oxford University, Oxford.

Hill, M. O. (1973), Diversity and evenness: a unifying notation and its consequences. Ecology, 54, 427-432.

Jonson, D. M.; Ruthrauff, D. R.; Jones, J. G.; Tietz, J. R. and Robinson J. K. (2001), Short-term effects of tatar emetic on re-sighting rates of migratory songbirds in the non-breeding season. $J \quad$ Field Ornithol, 73 (2), 191-196.

Kattan, G. H.; Lópes, H. A. and Giraldo, M. (1994), Forest fragmentation and bird extinctions: San Antonio eight years later. Conserv Biol, 8 (1), 138146.

Klein, B. C. (1989), Effects of forest fragmentation on dung and carrion beetle communities in central Amazonia. Ecology, 70, 1715-1725.

Lanyon, S. M. (1987), Jackknifing and bootstrapping: important "new" statistical techniques for ornithologists. The Auk, 104, 144-146.

Lovejoy, T. E.; Bierregaard, R. O.; Ranking, J. M. and Schubart H. O. R. (1983), Forest fragmentation effects on birds. In- Ecological dynamics of forest fragments ed. Sutton, S.L., T. C. and Witmore A. C. Conservation Biology, 10 (1), 188-202.

Lovejoy, T. E.; Bierregaard, R. O.; Rylands, A. B.; Malcom, J. R.; Quintela, C. E.; Harper, L. H.; Brown, K. S.; Powell, A. H.; Powell, G. V. N.; Schubart, H. O. R. and Hays M. S. (1986), Edge and other effects of isolation on Amazon forest fragments. InConservation Biology: the science of scarcity and diversity, ed. Soulé M. E. Sinauer Associates, Sunderland, M.A., pp. 257-285

Malcolm, J.R. (1997), Insect biomass in Amazonian forest fragments. In- Canopy Arthropods, ed. Stork, N. E.; Adis, J. and Didham, R. K..Chapman and Hall, London, UK.

Mallet-Rodrigues, F.; Alves, V. S., e Noronha M. L. M. (1997), O uso de tártaro emético no estudo de alimentação de aves silvestres no estado do Rio de Janeiro. Ararajuba, 5 (2), 219-228.

May, R. M. (1975), Patterns of species abundances. InEcology and evolutions of communities, ed. Cody M. L. and Diamond J. M.. Belknap Press, Cambridge, MA, pp. 81-120.

Offerman, H. L.; Dale, V. H.; Pearson, S. M.; Bierregaard, R. O. and O'Neill, R.V. (1995), Effects of forest fragmentation on Neotropical fauna: current research and data availability. Environ Rev, 3, 191211.

Poulin, B.; Lefebvre, G. and McNeil, R. (1994a), Effect end efficiency of tartar emetic in determining the diet of tropical land birds. The Condor, 96, 98-104.

Poulin, B.; Lefebvre, G. and McNeil R. (1994b), Characteristics of feeding guilds and variation in diets of bird species of three adjacent tropical sites. Biotropica, 26 (2), 187-197.

Poulin, B.; Lefebvre, G. and McNeil R. (1994c), Diets of land birds from northeastern Venezuela. The Condor, 96, 354-367.

Robinson, S. K. and Holmes, R. T. (1982), Foraging behavior of forest birds: the relationships among search tactics, diet, and habitat structure. Ecology, 63 (6), 1918-1931. 
Rosenberg, K. V. (1993), Diet selection on Amazonian antwrens: consequences of substrate specialization. The Auk, 110 (2), 361-375.

Salati, E.; Ribeiro, M. N. G.; Absy, M. L. and Nelson, B. W. (1991), Clima da Amazônia: Presente, Passado e Futuro. In- Bases Científicas para Estratégias de Preservação e Desenvolvimento da Amazônia: Fatos e Perspectivas, V.1; ed. Val, A. L.; Figliuolo, R. and Feldberg, E., Instituto Nacional de Pesquisas da Amazônia, Manaus, pp. 21-34.

Sekercioglu, C. H; Ehrlich, P. R.; Daily, G. C.; Aygen, D.; Goehring, D. and Sandi, R. F. (2002), Disappearance of insectivorous birds from tropical forest fragments. Proc Natl Acad Sci USA, 99 (1), 263-267.

Sherry, T. W. (1984), Comparative dietary ecology of sympatric insectivorous Neotropical flycatchers (Tyrannidae). Ecol Monogr, 54 (3), 313-338.

Sherry, T. W. (1990), When are birds dietary specialized? Distinguishing ecological from evolutionary approaches, In- Avian foraging: theory, methodology, and applications ed. Morrison, M. L.; Ralph, C. J.; Verner, J. and Jehl, J. R. Studies on Avian Biology 13. Allen Press, Lawrence, K.S. pp. 337-352.

Sokal, R. R. and Rohlf, F. J. (1981), Biometry. Freeman, W. H. and Co., San Francisco, CA.

Souza, O. F. F. (1989), Diversidade de térmitas (Isoptera) e sua relação com a fragmentação de ecossistemas na Amazônia Central. Dissertação de Mestrado, Viçosa - MG, Brasil.
Souza, O. F. F. and Brown, V. K. (1994), Effects of habitats fragmentation on Amazonian termite communities. J Trop Ecol, 10, 197-206.

Stouffer, P. C. and Bierregaard, R. O. (1995), Use of Amazonian forest fragments by understory insectivorous birds. Ecology, 76 (8), 2429-2445.

Stouffer, P. C. (1997), Interspecific aggression in Formicarius ant thrushes? The view from Central Amazonian Brazil. The Auk, 114 (4), 780-785.

Stratford, J. A. (1997), The effects of fragmentation on terrestrial insectivorous birds in central Amazonas, Brazil. Master Thesis, Rutgers University, USA.

Stratford, J. A. and Stouffer, P. C. (1999), Local extinctions of terrestrial insetivorous birds in a fragmented landscape near Manaus, Brazil. Conserv Biol, 13 (6), 1416 - 1423.

Vasconcelos, H. L. (1988), Distribution of Atta (Hymenoptera-Formicidae) in "Terra-firme" rain forest in Central Amazonia: density, species composition and preliminary results on effects of forest fragmentation. Acta Amaz, 18, 309-315.

Received: March 26, 2009; Revised: September 02, 2009; Accepted: April 13, 2010 